\title{
GEOTURISMO E ROTEIROS TURÍSTICOS: PROPOSTAS PARA O PARQUE NACIONAL DE UBAJARA, CEARÁ, BRASIL
}

\author{
GEOTOURISM AND TOURISM ROUTES: PROPOSALS TO UBAJARA NATIONAL PARK, CEARÁ, BRAZIL
}

\section{RESUMO}

Nas últimas duas décadas o geoturismo tem se erguido enquanto uma atividade turística em escala global. Instrumentos de divulgação, comum às atividades consolidadas, estão sendo apropriados pelo trade turístico para a sua divulgação, dentre os quais os roteiros são um destaque. Dessa forma, o presente artigo objetiva erguer um diálogo entre o geoturismo e o processo de roteirização turística. Para tal foram realizados uma ampla discussão teórica e um estudo de caso, caracterizado pela construção de três roteiros geoturísticos para o Parna Ubajara, Ceará. Nota-se a capacidade dos roteiros geoturístico em difundir conceitos e práticas inerentes à temática da Geoconservação, além de salientar a importância do geopatrimônio na conservação ambiental. Os roteiros propostos para o Parna Ubajara demonstram a vocação geoturística, uma vez que quase a totalidade dos atrativos perpassam pela interação do geopatrimônio com a biodiversidade e a cultura local. A consolidação de roteiros geoturísticos ergue-se então enquanto uma possibilidade para a diversificação da oferta turística local. Por fim, é salientado que a metodologia adotada pode ser replicada em diferentes áreas, urbanas ou rurais, que apresentem potencial geoturístico.

Palavras-chave: Roteirização turística. Geopatrimônio. Geoconservação. Roteiros geoturísticos. Geodiversidade.

\section{ABSTRACT}

Geotourism arises as a tourist activity in the last two decades. Publicity instruments common to the global scale touristic activities are appropriated by the tourism industry, among then tourist route are a highlight. Thus, the present article aims to develop a dialoge between geotourism and the touristc routes creation process. We largely discuss the theory and a case study, characterized by the construction of three geotouristic routes for the Ubajara National Park, in Ceará, Brazil. We note the geotouristic routes have a capacity to diffuse concepts and practices concerning geoconservation, as well as to emphasize the geoheritage importance in the context of environmental preservation. The tourist routes proposed for the Ubajara National Park show its touristic aptitude, since all its attractions are related to the interaction between geoheritage, biodiversity and local culture. Then, the geotouristic routes consolidation rises as an additional possibility touristic offer diversification. Finally, we stress that the adopted methodology can be replicated in different areas, urban or rural, that present touristic potential.

Keywords: Tourist routes. Geoheritage. Geoconservation. Geotoutistic routes. Geodiversity.

\author{
Suedio Alves Meira ${ }^{a}$ \\ iD Marcos Antonio Leite do \\ Nascimento ${ }^{\text {b }}$ \\ (D) Edson Vicente da Silva ${ }^{a}$ \\ ${ }^{a}$ Universidade Federal do Ceará (UFC), \\ Fortaleza, CE, Brasil \\ ${ }^{\text {b }}$ Universidade Federal do Rio Grande do \\ Norte (UFRN), Natal, RN, Brasil
}

DOI: $10.12957 /$ geouerj.2020.39943

Correpondência: suediomeira@gmail.com

Recebido em: 4 fev. 2019

Aceito em: 6 fev.2020 


\section{INTRODUÇÃO}

Os roteiros turísticos constituem ferramentas utilizadas por diferentes atores do trade turístico para valorizar e divulgar as potencialidades de um território. Existem diversos roteiros disponíveis, desde aqueles que tomam como fio condutor um tema aos que apresentam caráter geral e elencam a totalidade de atrativos de uma determinada área. Nesse contexto, os roteiros são elementos prioritários no planejamento de qualquer atividade ou segmento turístico, sendo uma forma de dialogar com o seu público alvo.

O geoturismo tem crescido enquanto prática turística nas últimas duas décadas, firmando-se enquanto uma atividade de escala global que passeia entre o turismo industrial e o pós-turismo. Espaços turísticos em todo o mundo têm atrelado parcelas dos seus atrativos naturais e culturais aos postulados sustentáveis da prática geoturística, havendo destinos que apresentam nelas a base para o desenvolvimento socioeconômico (sendo os geoparques os melhores exemplos). Ferramentas turísticas foram adaptadas aos objetivos e à forma de apropriação do espaço realizada pelo geoturismo, dentre as quais estão os roteiros.

A formulação de roteiros geoturísticos atua como uma via de mão dupla. Por um lado, tem a capacidade de divulgar os locais de relevância geológica e as possíveis práticas a serem realizadas pelo grande público, incentivando o turista a trocar atividades relacionadas a segmentos consolidados, como o de sol e praia ou o ecoturismo, pelo geoturismo. Por outro lado, é uma forma utilizada pelos gestores de organizar o uso das potencialidades naturais e culturais, sendo um retrato socioeconômico e ambiental do destino geoturístico.

As áreas que apresentam potencialidades para o desenvolvimento do geoturismo devem ter a formulação de roteiros como um instrumento amplamente aplicável. O presente artigo tem por objetivo propor roteiros geoturísticos para o Parna Ubajara, noroeste do estado do Ceará, enquanto meio de dinamizar as práticas turísticas e incrementar recursos e atrativos turísticos.

O Parna Ubajara engloba parte dos municípios cearenses de Ubajara, Tianguá e Frecheirinha (Figura 1), é uma das Unidades de Conservação (UCS) mais antigas do Brasil, sendo instituída em 30 de abril de 1959. O objetivo prioritário para instituição da UC foi a conservação do complexo espeleológico de Ubajara, o mais importante em contexto estadual, e a interação com a floresta pluvionebular do front do Planalto da Ibiapaba, apontada como remanescente da Mata Atlântica. 
Figura 1. Mapa de localização geográfica do Parque Nacional de Ubajara. Fonte: Autoria própria.

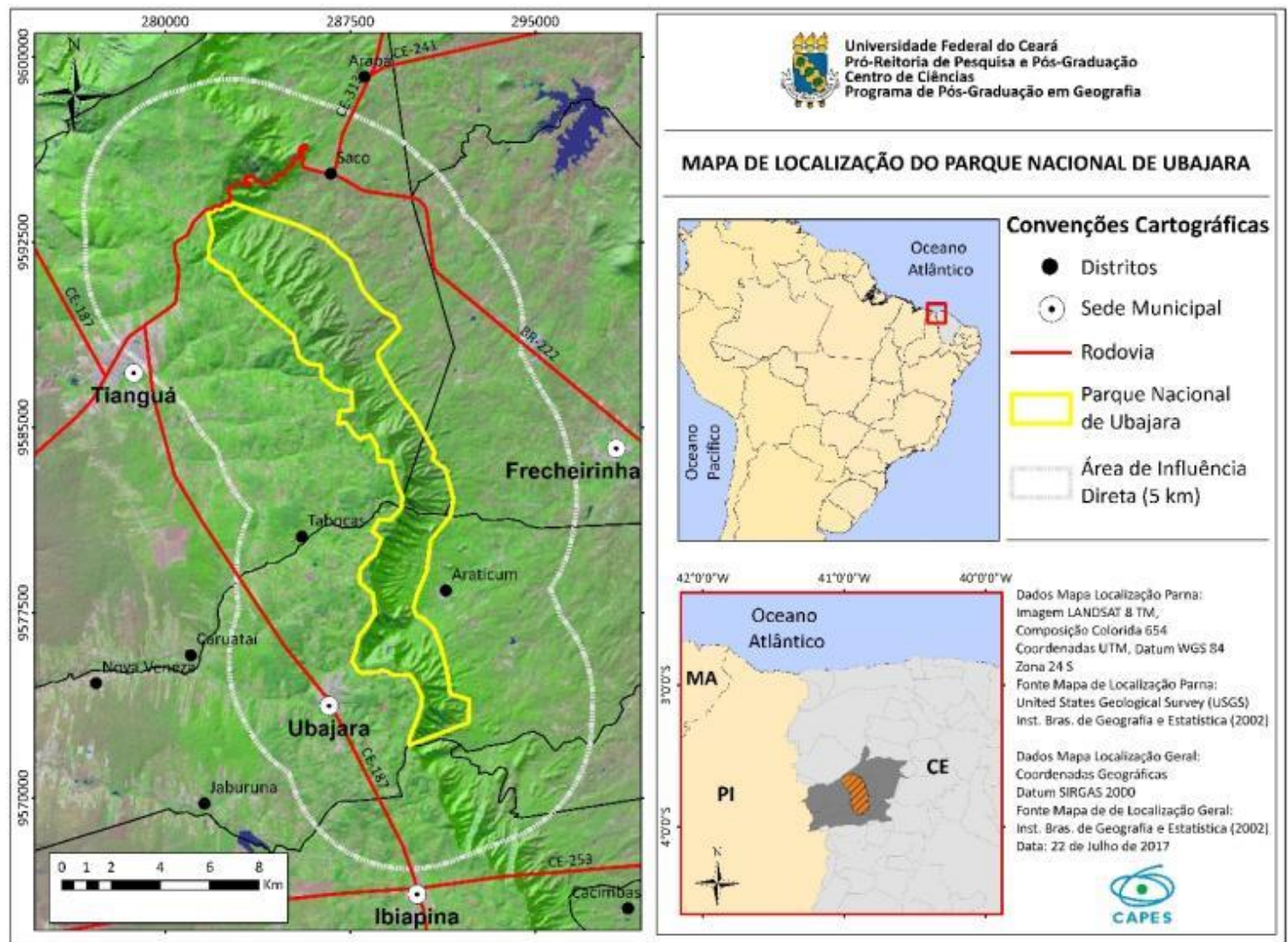

No ano de 2002, o Parna Ubajara passou por uma expansão territorial, deixando os 564 ha para os atuais

6.288ha de área. Apesar do incremento espacial, nota-se que as atividades ligadas ao turismo continuaram a ser realizada com foco no antigo perímetro, que engloba a Gruta de Ubajara e o seu entorno imediato. Dessa forma, o presente artigo também visa auxiliar no levantamento e descrição de recursos e atrativos turísticos presentes na área de expansão, uma vez que o Parna Ubajara apresenta potencial para se firmar enquanto um dos principais destinos turísticos de natureza no território nacional.

\section{Metodologia}

Os procedimentos metodológicos iniciaram-se a partir de um levantamento bibliográfico sistemático sobre o ambiente natural e as condições socioeconômicas dos municípios que integram o Parna Ubajara. Também foram pesquisados bancos de teses, dissertações, revistas e livros científicos os postulados teóricos referentes à temática do geoturismo e sobre o processo de roteirização turística. Essa etapa serviu de base para as ações posteriores, especialmente na definição dos objetivos do inventário.

A segunda etapa metodológica foi compreendida pela realização de trabalhos de campo para o inventário dos geossítios', os quais configuram-se como atrativos e recursos turísticos passíveis de utilização em práticas geoturísticas, sendo realizados três trabalhos de campo, totalizando 15 dias, entre os anos de 
2016 e 2018. A etapa de inventário resultou na definição de onze geossítios enquanto recursos e/ou atrativos geoturísticos. Salienta-se que o inventário seguiu o procedimento realizado por Meira (2020, no prelo), que tem como objetivo salientar locais com valor turístico e educativo.

Após o inventário, foi realizada uma avaliação qualitativa referente a presença de infraestrutura de suporte às atividades turísticas, tendo como foco aspectos referentes à acessibilidade, presença de estruturas físicas e de elementos de caráter cultural associados. Também foi efetivada uma descrição das características geológicas e geomorfológicas de cada geossítio, salientando quais aspectos apresentam-se como potencialidades para o geoturismo.

Posteriormente, foi confeccionado um desenho preliminar dos roteiros geoturísticos por meio da análise das distâncias entre os geossítios, os conteúdos presentes e o tempo necessário para visitas satisfatórias. Por fim, foram elaboradas três propostas de roteiros geoturístico para o Parque Nacional de Ubajara, sendo que para cada uma foi confeccionado um folheto turístico-educativo.

Os folhetos foram desenhados no programa Adobe Illustrator CC 2015, e as fotografias utilizadas foram tratadas no programa Adobe Lightroon, buscando melhoria nos aspectos de nitidez, saturação, balanço de brancos, entre outros. Os três folhetos apresentam desenho semelhante, com adaptações pontuais nos textos de capa, fundo e interior (descrição dos geossítios) e na cor. Os textos empregados foram revisados por uma profissional da área da Comunicação Social (Publicidade e Propaganda), visando trazer fluidez a leitura.

\section{Geoturismo: uma prática em discussão}

Apesar do interesse em visitar locais com características geológicas ser uma atividade antiga, o geoturismo, enquanto prática turística, está em uma fase inicial. Não há consenso quanto ao conceito, bem como se ele se configura como um novo segmento turístico, quais são os reais produtos ou se dispõe de públicos específicos, ou se ele é apenas uma vertente atrelada ao ecoturismo e ao turismo científico. Em meio a essas incertezas teóricas pretende-se discutir perspectivas elencadas por pesquisadores da temática, assim como levantar novos questionamentos.

Hose (1995) foi quem primeiro formulou um conceito para geoturismo, definindo-o enquanto uma atividade turística responsável pela provisão de serviços e facilidades interpretativas que permitem aos turistas adquirirem conhecimento e entendimento sobre a geologia e geomorfologia do local, indo além de mera apreciação estética.

Desde a sua gênese, o geoturismo apresenta um caráter educativo-científico, estando pautado em experiências interpretativas. Sua base seria a instituição de atividades que traduzam os aspectos abióticos da 
natureza para uma linguagem das pessoas, integrando turista e paisagem por meio de experiências significativas, provocantes, diferenciadas, temáticas, organizadas e prazerosas (TILDEN, 1997).

Cinco anos após a primeira conceituação, Hose (2000) traz uma reformulação, onde aprofunda o caráter geoconservacionistas do geoturismo. Tal fato aproxima a prática do paradigma da sustentabilidade, compreendendo-a enquanto uma ação que, se planejada adequadamente, pode ser repetida por tempo indefinido, tendo em consideração os eixos ambiental, sociocultural e econômico (BRILHA, 2005).

Azevedo (2007, p. 23), pautada nas definições do Ministério do Turismo, apresenta um conceito que aborda o geoturismo como um segmento turístico próprio relacionado ao uso do geopatrimônioii, enquanto recurso e atrativo. Segundo a autora, o geoturismo configura:

\begin{abstract}
(...) um segmento da atividade turística que tem o patrimônio geológico como seu principal atrativo e busca sua proteção por meio da conservação de seus recursos e da sensibilização do turista, utilizando, para isso, a interpretação desse patrimônio tornando-o acessível ao público leigo, além de promover a sua divulgação e o desenvolvimento das ciências da Terra.
\end{abstract}

No âmbito acadêmico, o geoturismo é conceitualmente abordado em duas perspectivas distintas. Há autores que apontam como seu foco principal os aspectos geológicos (NEWSOME; DOWNLING, 2018), enquanto alguns defendem uma abordagem ampla e geográfica (NATIONAL GEOGRAPHIC, 2018). Essa diferenciação conceitual é uma das principais divergências entre os estudiosos do tema.

A National Geographic foi a primeira, no ano de 2010, a apresentar um conceito pautado no caráter geográfico do geoturismo. Segundo a sociedade, o mesmo seria o "turismo que sustenta ou valoriza o caráter geográfico único de um lugar - seu meio ambiente, patrimônio, estética, cultura e o bem-estar de seus moradores" (NATIONAL GEOGRAPHIC, 2018). Esse conceito gerou críticas severas no âmbito acadêmico, uma vez que "esqueceu" toda uma corrente teórica anteriormente produzida, ao não pontuar a interação e a importância dos aspectos geológicos. Outras críticas partem da semelhança do conceito com os de outros segmentos já consolidados, não havendo um diferencial, como exemplo, entre o geoturismo e a qualquer tipologia de turismo de base local.

Buscando conciliar as duas abordagens teóricas e alçar um conceito geral, a Declaração de Arouca, formulada durante o 1 o Congresso Internacional de Geoturismo, realizado em Arouca (Portugal) no ano de 2011, traz uma definição de geoturismo que passou a ser amplamente adotada. Segundo a Declaração, o geoturismo é:

(...) o turismo que sustenta e incrementa a identidade de um território, considerando a sua geologia, ambiente, cultura, valores estéticos, património e o bem-estar dos seus residentes. O turismo geológico assume-se como uma das diversas componentes do geoturismo (AROUCA, 2011, grifo do autor). 
A Declaração de Arouca, ao inserir no conceito o termo "geologia", diferenciou a prática geoturística das demais aportando uma identidade própria, que atribui destaque aos elementos da geodiversidade e que fortalece a sua concepção sistêmica, a qual deve gerar benefícios para e por meio da conservação ambiental, da geoeducação, da interpretação do geopatrimônio e da economia. No geoturismo são fundamentais a valorização e a apropriação da identidade territorial, uma vez que as inter-relações entre os aspectos culturais e ambientais (abióticos e abióticos) configuram, ao mesmo tempo, produtos e objetivos de ação.

Contudo, apesar dos avanços, teria sido mais interessante e importante que a Declaração de Arouca tivesse utilizado o termo "geodiversidade" ao invés de "geologia", já que isso propiciaria uma maior associação com a temática base dessa atividade e retiraria a redução que o termo usado pode acarretar.

Downling (2013) expõe cinco fundamentos básicos para o geoturismo: (i) O geoturismo é embasado nos aspectos geológicos, com foco nos elementos do geopatrimônio, (ii) ele deve ser sustentável, o que inclui tanto os aspectos ligados à conservação ambiental, como os que contemplam a viabilidade econômica. (iii) $\mathrm{O}$ geoturismo deve ser educativo, mas não maçante, sendo alicerçado na geointerpretação. A educação é a base do geoturismo, uma vez que ao receber informações, por meio de diversos instrumentos, o turista aprende tanto sobre a geodiversidade como a reconhecer os demais valores atrelados aos aspectos ambientais e culturais. (iv) 0 geoturismo deve ser benéfico aos espaços receptores, atuando enquanto ferramenta no desenvolvimento territorial local. (v) O geoturismo deve gerar satisfação turística. Não adianta uma prática dotada das melhores intensões para com o meio ambiente e os locais receptores se ela não consegue cativar e provocar o público, gerando fluxos e rentabilidade econômica.

Diante o exposto, é certo pontuar que o geoturismo configura-se como uma nova atividade turística, uma vez que apresenta aportes teórico-metodológicos, produtos e filosofias diferenciadas. Moreira (2010), expõe que o geoturismo deve ser encarado enquanto um novo segmento por apresentar potencialidades, características e objetivos próprios ao buscar a interação entre a paisagem e os aspectos científicos e culturais, salientando elementos negligenciados no ecoturismo, como a geodiversidade.

Outro viés para definição de um segmento turístico é o mercadológico, há público para o geoturismo? Antes de responder esse questionamento é válido pontuar outra característica que ajuda a decifrar esse ponto. O geoturismo é um segmento que apresenta características de um turismo pós-industrial, sendo marcado pela diferenciação de produtos e serviços, por ser uma alternativa ao turismo de massa, por apresentar atividades personalizadas e prezar pela hospitalidade (CISNE, 2016).

O geoturismo apresenta também qualidades de uma prática do pós-turismo, que configura um novo paradigma e é marcado pela experiência, mediante ao fato que uma nova parcela dos públicos "não buscam 
por novos destinos, mas por novas experiências. O turista passa de espectador à protagonista, assumindo papeis mais ativos e interagindo física e mais intensivamente com os destinos" (CISNE, 2016, p. 11).

O geoturismo tem nas experiências com o meio ambiente e com a população local um dos seus principais atrativos. O geoturismo também pode ser realizado em conjunto com outras práticas turísticas tradicionais, tanto em zonas rurais como nas cidades, o que concede a ele a dinamicidade tão esperada pelos pós-turistas. O fato de ser realizado também em ambientes urbanos diferencia o geoturismo do ecoturismo, uma vez que o segundo se apropria apenas de espaços naturais

Uma estratégia que tem alcançado sucesso e que apresenta o geoturismo como base para o desenvolvimento territorial é a instituição de Geoparques (Geoparks, em inglês). Os Geoparques são definidos enquanto "áreas geográficas únicas e unificadas, onde locais e paisagens de significado geológico internacional são gerenciados por meio de um conceito holístico de proteção, educação e desenvolvimento sustentável" (UNESCO, 2018, tradução nossa). Essa estratégia de gestão nasceu no ano 2000 com a Criação da Rede Europeia de Geoparques, que contava com apenas quatro territórios europeus que apresentavam atrativos geológicos e culturais excepcionais, mas passavam por problemas de caráter socioeconômico, especialmente a migração de população local para os grandes centros urbanos (ZOUROS, 2004).

O sucesso dessa estratégia de valorização territorial foi rapidamente reconhecido em escala global. Fato esse que resultou na expansão em 2004, na efetivação da Rede Global de Geoparques (Global Network of National Geoparks), sob auspício da UNESCO. Durante a 38a Conferência Geral da UNESCO, realizada em 17 de novembro de 2015, foi aprovado o UNESCO Global Geoparks, e os geoparques mundiais passaram a ser um programa específico da organização, dispondo de suporte direto da própria UNESCO (BRILHA, 2018).

Após vinte anos, o número de geoparques passou de 4 para 147 territórios, em 41 países (em abril de 2019), demonstrando que o programa é uma estratégia efetiva de gestão territorial. Esse exemplo de sucesso permite responder o questionamento lançando, e chegar à conclusão que há sim um púbico para o geoturismo. Uma vez que se não houvesse pessoas interessadas nos produtos e nos atrativos disponibilizados pela prática geoturísitica os geoparques não teriam alcançado reconhecimento e se alicerçado no cenário mundial.

Quanto ao público é necessário entender que ele é múltiplo, como o próprio geoturismo. Downling (2013) atribui cinco públicos de acordo aos interesses, objetivos e graus de satisfação. Há o "geoturista proposital", cuja a principal motivação da viagem é visitar um geossítio e ter uma experiência positiva. Geralmente, esse público apresenta certo conhecimento sobre as geociências. Existe o "geoturista intencional" que tem a motivação influenciada pelo geossítio e desfruta das informações disponíveis. 
Para o "geoturista inesperado" o geopatrimônio desempenha papel moderado na tomada de decisão de visitar ou não ao local. Já a motivação do "geoturista acidental" não é influenciada pelo geoturismo, comumente o mesmo não é ciente de estar visitando um local de relevância geológica até o momento. E por fim, há o grupo dos "geoturista incidental" onde o geoturismo não desempenha nenhum papel significativo na escolha do destino e as experiências relacionadas ao geoturismo são consideradas negativas. $\mathrm{O}$ conhecimento do tipo de público que visita um local com potencial para o geoturismo ou que já realiza práticas atreladas a esse segmento é de fundamental importância no desenvolvimento de produtos e materiais especializados, dentre os quais os roteiros geoturísticos adquire destaque.

\section{Roteiros Turísticos e Geoturismo: um diálogo necessário}

Os roteiros turísticos aparecem na literatura especializada em diferentes termos, como circuitos, excursões, itinerários, pacotes turísticos (SPINDLER, 2013). De uma forma simplista o roteiro turístico pode ser definido enquanto um método eficaz de distribuição do turismo em uma determinada área, possibilitando a ligação entre os atrativos por meio de um itinerário de visitação organizado (SCHERER, 2014).

Os roteiros turísticos existem em todos os espaços que sediam essa atividade, respondendo a diferentes escalas (do local ao internacional), ambientes (urbanos ou rurais) e buscam integrar as potencialidades paisagísticas e culturais dos destinos turísticos, otimizando o tempo e as experiências dos visitantes. Por ser um retrato dos recursos, atrativos e infraestruturas de suporte, os roteiros configuram uma leitura da situação sociocultural e ambiental vigente no local (TAVARES, 2002). A visão mercadológica é bastante presente, sendo esse fato explicitado na definição alçada pelo Ministério do Turismo (BRASIL, 2007, p. 13), que aborda os roteiros turísticos como

\footnotetext{
(...) um itinerário caracterizado por um ou mais elementos que the conferem identidade, definido e estruturado para fins de planejamento, gestão, promoção e comercialização turística das localidades que formam o roteiro. Partindo da definição anterior, pode-se dizer que a roteirização turística é o processo que visa propor, aos diversos atores envolvidos com o turismo, orientações para a constituição dos roteiros turísticos. Essas orientações vão auxiliar na integração e organização de atrativos, equipamentos, serviços turísticos e infraestrutura de apoio do turismo, resultando na consolidação dos produtos de uma determinada região.
}

Cisne (2016) aponta a necessidade de se pensar os roteiros turísticos de forma mais aprofundada, saindo das abordagens simplistas e mercadológicas para um enfoque pautado na complexidade. A autora expõe os roteiros enquanto a força motriz da atividade turística, ou seja, aquele responsável por trazer o efeito de movimento ao turismo. Para pensar o roteiro turístico pautado na complexidade é necessário integrá-lo ao paradigma do pós-turismo. O roteiro turístico pós-moderno deve ser tratado como um meio de orientar o fluxo turístico, "indicando caminhos e propondo, por meio da subjetividade, emoção e percepção de cada 
sujeito que o realiza, atividades a serem vivenciadas ao longo do espaço físico percorrendo seus significados, atribuindo ao espaço, o sentido e o valor de lugar" (CISNE, 2016, p. 14).

Os roteiros turísticos podem ser organizados ou espontâneos, comercializados ou não, incentivados pela iniciativa privado ou pública. Porém, todos apresentam alguns objetivos base que partem de oferecer ao consumidor o maior número de informações de forma objetiva, visando apresentar o destino e as suas potencialidades de forma a aguçar o interesse nos turistas em visitar cada atrativo, além de "organizar as visitações da melhor forma possível, de acordo com as possibilidades técnicas, levando em consideração os interesses do turista ou grupo de turistas" (SILVA;NOVO, 2010, p. 39).

Nesse contexto, pergunta-se como integrar o geopatrimônio nos roteiros turísticos? Os elementos que compõem o geopatrimônio podem atuar enquanto recursos, atrativos ou produtos naturais na prática turística. Os recursos são os elementos que podem atrair turistas, por sua vez os atrativos são os recursos que já apresentam procura turística, já o produto é quando há em torno do atrativo turístico um conjunto de atividades relacionadas como transporte, hospedagem, entre outros (RICHTER et al., 2016).

Nota-se que os principais atrativos e produtos turísticos em ambientes naturais são de caráter geológico-geomorfológico. Como exemplo, toma-se algumas das Unidades de Conservação mais visitadas do Brasil. O Parque Nacional do Iguaçu (PR), que tem nas cataratas do rio Iguaçu o principal atrativo, apresenta todo um aparato físico e econômico construído. Por sua vez, no Parque Nacional de Fernando de Noronha $(P E)$, são o mar, as praias e as formações rochosas que configuram-se como alvos de desejo dos visitantes. Em ambientes urbanos também ocorrem atrativos atrelados ao geopatrimônio, vide o Pão de Açúcar na cidade do Rio de Janeiro, e os diversos parques localizados em antigos espaços de mineração na cidade de Curitiba, estado do Paraná (MINEROPAR, 2008).

Diversos outros espaços no território nacional apresentam recursos turísticos vinculados ao geopatrimônio, cabendo o incentivo à visitação e ao estabelecimento de práticas de turismo sustentável atreladas ao geoturismo. Nesse contexto, é válido a formulação de roteiros temáticos direcionados, por meio da confecção de itinerários, assim, os postulados e os objetivos do geoturismo seriam popularizados, contribuindo para a consolidação dessa atividade enquanto segmento turístico. Esses roteiros geoturísticos devem ter como base os aspectos geológicos do local receptor, trazendo relações com a biodiversidade e a cultura presente, respondendo ao caráter integrador e dinâmico inerente à prática.

A confecção de roteiros turísticos é uma atividade complexa e multidisciplinar. O processo de roteirização perpassa por onze etapas que englobam desde o envolvimento dos atores (as pessoas envolvidas no turismo local), ao levantamento e avaliação dos atrativos turísticos, à elaboração de roteiros específicos, à promoção e monitoria dos roteiros (BRASIL, 2007). Todas essas etapas devem integrar a construção dos 
roteiros geoturísticos, entretanto as mesmas devem ser adaptadas às características educativas, conservacionistas e identitárias que são o alicerce do geoturismo.

\section{Roteiros Geoturísticos para o Parque Nacional de Ubajara}

O Parque Nacional de Ubajara apresenta uma grande diversidade de recursos e atrativos geológicos capazes de serem utilizados em práticas ligadas ao geoturismo. A área já configura um importante destino turístico no âmbito estadual, sendo que a sua relevância reflete na economia dos municípios. Segundo dados disponibilizados pela gestão da unidade, entre os anos de 1990 e 2017, o Parna Ubajara foi visitado por 1.800.158 pessoas (Tabela 1), uma média de 66.710 visitantes ao ano.

Esses dados contrastam com a reduzida população das cidades que compõem o Parna Ubajara, que segundo estimativas do Instituto Brasileiro de Geografia e Estatística para o ano de 2018 era de 75.140 habitantes para o município de Tianguá, 34.530 para Ubajara e 13.758 para Frecheirinha, totalizando 123.428 habitantes. Nota-se que grande parte dos visitantes do Parna Ubajara são turistas oriundos de outras cidades, especialmente do estado do Ceará e do Piauí, que se hospedam, prioritariamente, nas sedes municipais de Ubajara e Tianguá. Esses turistas ajudam a dinamizar a economia local, possibilitando a implantação de estabelecimentos de suporte ao turista, compostos por opções variadas de hospedagem e restaurantes.

Tabela 1. Balanço de visitantes do Parna Ubajara entre os anos de 1990 e 2017. Fonte dos dados: Direção do Parque Nacional de Ubajara (2018).

\begin{tabular}{cccc}
\hline Ano & Número de Visitantes & Ano & Número de Visitantes \\
\hline 1990 & 15.477 & 2004 & 47.852 \\
1991 & 63870 & 2005 & 42.089 \\
1992 & 62.604 & 2006 & 51.440 \\
1993 & 50.604 & 2007 & 53.796 \\
1994 & 58.094 & 2008 & 72.310 \\
1995 & 58.323 & 2009 & 78.214 \\
1996 & 68.500 & 2010 & 96.667 \\
1997 & 55.753 & 2011 & 87.616 \\
1998 & 47.311 & 2012 & 98.817 \\
1999 & 46.858 & 2013 & 108.503 \\
2000 & 44.757 & 2014 & 108.580 \\
2001 & 43.076 & 2015 & 104.434 \\
2002 & 41.777 & 2016 & 70.765 \\
2003 & 48.297 & 2017 & 74.774 \\
\hline \multicolumn{2}{c}{ Total de Visitantes: 1.800 .158} & Média de visitantes por ano: 66.710 \\
\hline
\end{tabular}

Apesar do atual desenvolvimento turístico é possível notar que as atividades estão centradas em uma única área, compreendida pela Gruta de Ubajara e o seu entorno imediato, no município de Ubajara. Assim, a construção de roteiros geoturísticos que abarquem outros espaços do parque configura como uma estratégia na dinamização da atividade turística local, promovendo a dispersão dos fluxos. 
O caráter integrador do geoturismo permite que estratégias próprias sejam aplicadas em locais onde haja o predomínio de outras atividades turísticas. Esse é o contexto do Parna Ubajara, que apresenta práticas consolidadas de ecoturismo. As propostas formuladas visam ser uma ferramenta na dinamização da oferta turística, na melhor apropriação das potencialidades ambientais e culturais e no incremento de experiências satisfatórias aos turistas.

Os roteiros geoturísticos foram pensados com base no tempo cronológico que os visitantes dispendem no Parna Ubajara e o tipo de interesse turístico que apresentam. São propostos roteiros com duração de dois e três dias, e um exclusivo de cunho científico, que não indica uma sequência e tempo para a visitação dos geossítios.

Os dois primeiros roteiros foram pensados para um público caracterizado por "geoturistas acidentais", pessoas que descobrem as potencialidades do geopatrimônio no momento da visita e que apresentam pouco ou nenhum conhecimento específico sobre geologia ou geomorfologia. O tempo adotado está em função da grande parcela dos turistas visitam o Parna Ubajara em finais de semana ou feriados prolongados. Entretanto, os roteiros também podem ser utilizados por pessoas que vão passar mais ou menos tempo no parque, já que os materiais gráficos gerados dispõem de fotografias e textos interpretativos que auxiliam os turistas na escolha dos atrativos geoturísticos a visitar.

O roteiro científico foi construído para um público que busca conhecimento específico sobre o geopatrimônio do Parna Ubajara, integrando geossítios que não dispõem de tanto apelo cênico ou que possam abordar temas de maior complexidade. O roteiro é orientado a grupos educativos (especialmente para trabalho de campos de turmas do ensino superior relacionadas à vertente ambiental), grupos de adultos nãoespecializados, mas que procuram informações específicas, ou para grupo de pessoas aficionadas e especializadas.

Antes da apresentação dos roteiros é válido salientar que as propostas focaram em partes específicas do processo de roteirização, compreendendo o levantamento dos recursos e atrativos turísticos, a avaliação da infraestrutura presente e a elaboração de itinerários específicos. A confecção de um roteiro completo, seguindo os modelos disponíveis, só é possível por meio do trabalho de uma equipe multidisciplinar e da interação (e vontade política e econômica) dos atores envolvidos, sendo então uma atribuição do órgão gestor, dos governos municipais e da iniciativa privada local.

No roteiro de dois dias, são propostas visitas a sete geossítios. No primeiro dia é sugerido a visitação dos três geossítios localizados no município de Tianguá, na porção norte do Parna Ubajara, sendo eles Sítio do Bosco, Paredões de Janeiro e Cachoeira do Pinga. A proximidade entre os geossítios, integrados por menos de $21 \mathrm{~km}$ por estradas asfaltadas e vicinais, e a ausência de trilhas extensas permite a sua visitação em um dia. 
O Geossítio Sítio do Bosco está localizado no limite externo do Parna Ubajara, porém foi agregado ao roteiro por ser uma zona apropriada para práticas turísticas. O local fica a $10 \mathrm{~km}$ do centro urbano de Tianguá e integra o empreendimento particular do Sítio do Bosco Park, um produto ecoturístico consolidado. O local tem uma taxa de visitação ( $R$ \$ 5,00 por pessoa no ano de 2017), dispondo de uma adequada estrutura de apoio ao turista, contando com restaurantes, piscinas, camping, chalés e uma rampa para prática de parapente (Figura 2a, b).

Figura 2. a, b) Infraestruturas de suporte ao turista no Sítio do Bosco Park. c) Trilha da Caverna do Macaco. Foto: Autoria Própria

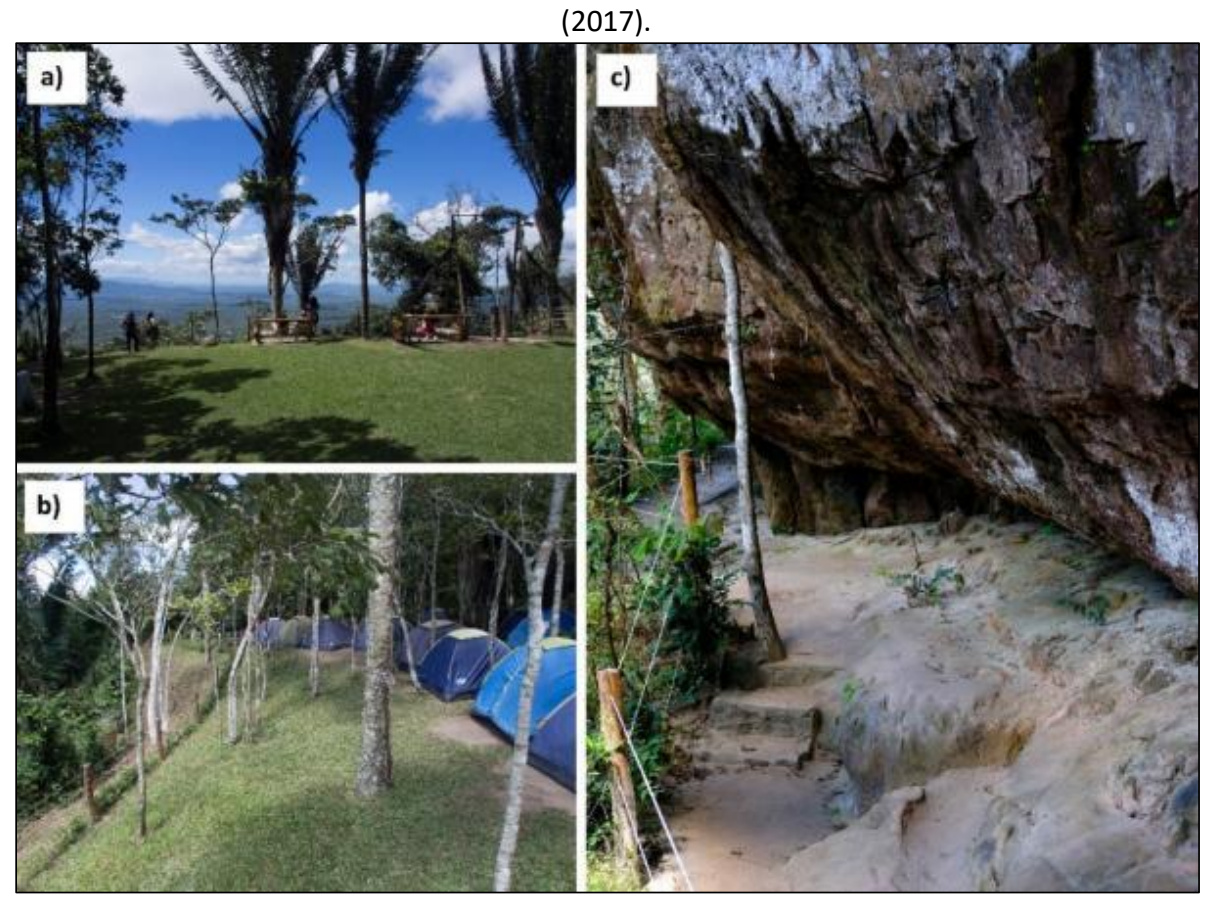

Os principais atrativos para o geoturismo parte do apelo cênico dos mirantes, que possibilitam explanações sobre a evolução geomorfológica da vertente oeste do Planalto da Ibiapaba. Outros atrativos são as trilhas sinalizadas da Caverna do Morcego (Figura 2c), localizadas na zona de escarpa favorecendo as explicações sobre a geologia sedimentar e aspectos referente ao relevo cárstico em arenitos.

O Geossítio Paredões de Janeiro está a 7 km do centro urbano de Tianguá, sendo o local de mais difícil acesso devido ao estado da estrada vicinal, que durante o período chuvoso só é acessível por carros traçados. O local está inserido na zona de expansão do Parna Ubajara, concretizada no ano de 2002, não apresentando, no entanto, medidas de valorização turística. Outra característica é o fato da área não ter passado pelo processo de desapropriação territorial, sendo assim, ainda ocupado por comunidades nas proximidades do geossítio.

Os moradores dos Paredões de Janeiro configuram um recurso valioso para o desenvolvimento de práticas turísticas, já que constituem a memória viva local. Um exemplo é o Sr. Raimundo que reside a mais 
de cinco décadas em uma casa localizada na entrada da trilha de acesso ao geossítio e sempre recebe os visitantes com histórias sobre o local e sua toponímia. O valor cultural agregado por pessoas da comunidade faz com que seja necessário incluí-los como agentes prioritários em qualquer planejamento turístico. Quanto aos recursos e atrativos naturais passíveis de apropriação pelo geoturismo, o Geossítio Paredões de Janeiro apresenta, dentro de um mesmo contexto geológico, vistas panorâmicas como a da Pedra do Espia, fendas esculpidas em arenito (Figura 3a), paredões e uma cachoeira.

Figura 3. a) Fenda estrutural característica do Geossítio Paredões de Janeiro. b) Cachoeira do Pinga, presente no geossítio homônimo. Fotos: Autoria própria (2017 e 2018).

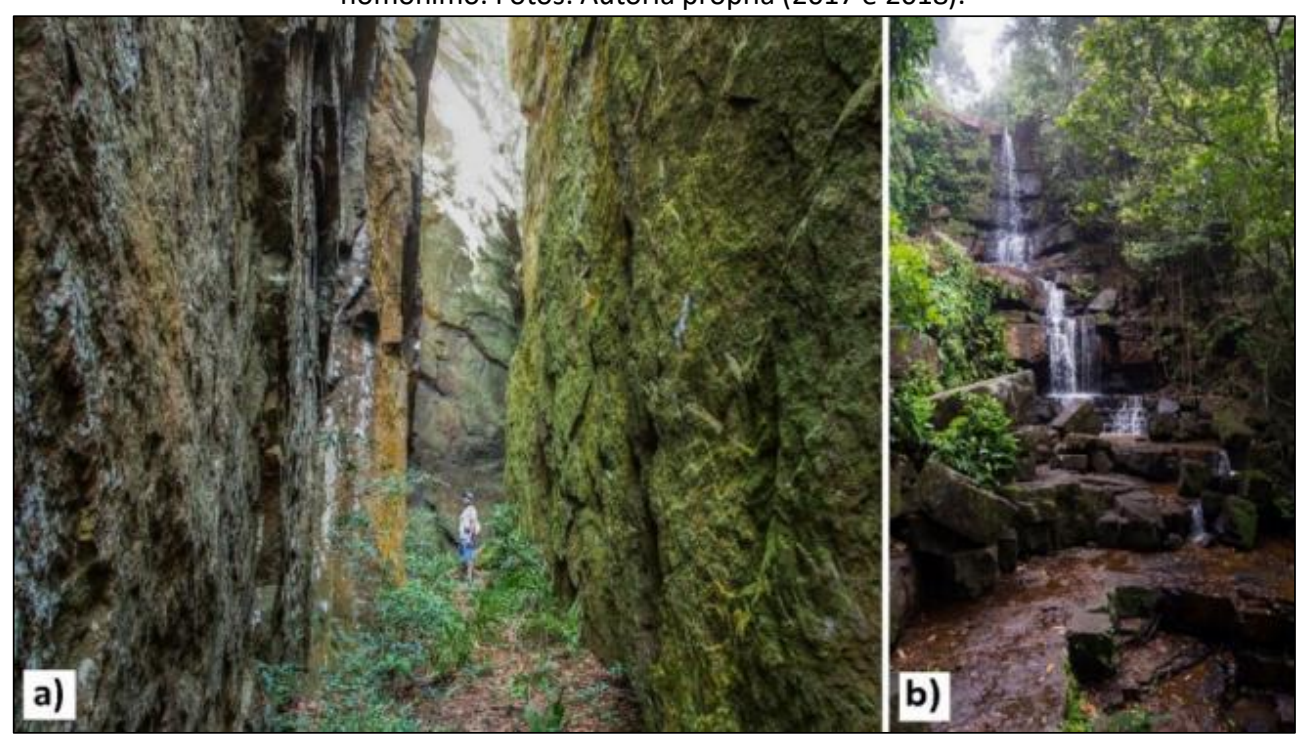

O Geossítio Cachoeira do Pinga (Figura 3b) também está localizado na área de expansão do parque, próximo ao povoado do Pinga. O local é de fácil acesso, sendo possível acessar por meio de estrada asfaltada, conhecida como Rodovia do Contorno Verde, que liga o centro urbano de Tianguá a distritos na zona rural. 0 local é bastante visitado para atividades de lazer das populações do entorno.

O atrativo principal para o geoturismo é a própria cachoeira, que se desenvolve em forma de degraus sobre a vertente (Figura 3b). A força das águas corta as camadas sedimentares do Grupo Serra Grande, expondo uma leve inclinação para interior da Bacia do Parnaíba. A Cachoeira do Pinga é acompanhada pela Trilha da Transumância que faz ligação do topo do Planalto da Ibiapaba com a Depressão Sertaneja, tendo sido a mesma utilizada no passado pelos índios Tabajara como rota de ligação entre a serra e o sertão, o fato atribui importância cultural ao local e também deve ser considerado.

Para um segundo dia, é proposta a visita aos geossítios da "parte antiga" do Parna Ubajara, localizados próximos à sede municipal de Ubajara, e que apresenta uma melhor infraestrutura de suporte ao turista, com trilhas bem definidas, centro de visitantes, lanchonete, entre outros recursos. São visitados os geossítios Mirante do Pendurado, Mirante da Gameleira, Circuito das Cachoeiras e Gruta de Ubajara. Esses geossítios 
estão próximos, sendo utilizado o teleférico para a visita ao Geossítio Gruta de Ubajara e os demais são conectados por uma trilha em área plana de $4 \mathrm{~km}$, que vai do Mirante do Pendurado à cachoeira do Gavião, no Geossítio Circuito das Cachoeiras.

Os Geossítios Mirante do Pendurado (Figura 4a) e Mirante da Gameleira (Figura 4b) possuem infraestruturas circulares em madeiras sobre a escarpa do Planalto da Ibiapaba, o que permite a visualização panorâmica da paisagem. A partir do Mirante do Pendurado é possível ter uma vista privilegiada da zona de escarpa, das superfícies sertanejas e do Morro do Pendurado, um cone cárstico formado por metacalcários onde estão esculpidas duas importantes cavernas do Parna Ubajara.

Figura 4. a) Vista panorâmica do Geossítio Mirante da Gameleira. b) Aspectos geomorfológicos visualizados do Geossítio Mirante do

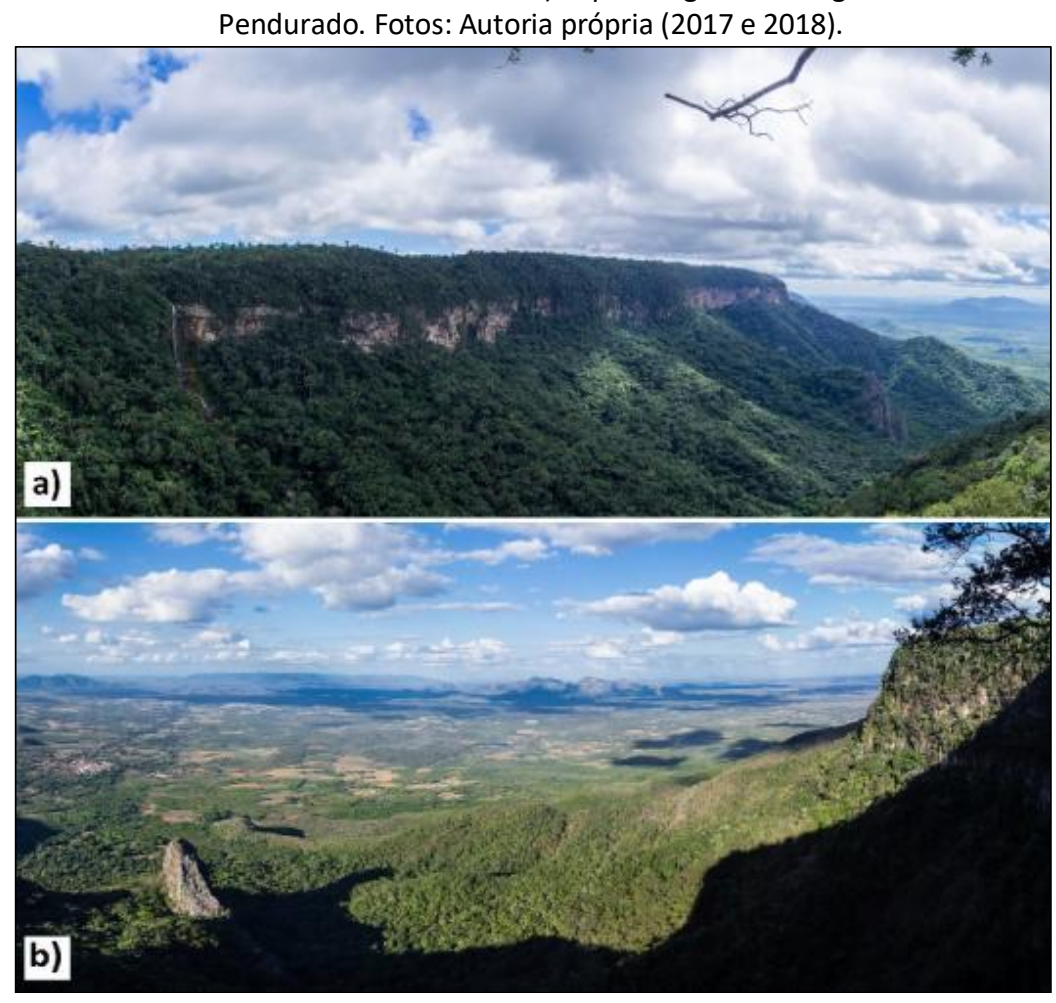

Do Mirante da Gameleira é possível ver, dependendo do período do ano, quatro cachoeiras dispostas sobre a zona da escarpa (cachoeiras da Gameleira, Cafundó, Gavião e Murimbeca), que chegam a ultrapassar os 70 metros de altitude. A sua localização em um anfiteatro erosivo permite explanações sobre a evolução geomorfológica regional por meio do entendimento do recuo erosivo das suas vertentes.

O Geossítio Circuito das Cachoeiras compreende uma área entre as cachoeiras do Cafundó e do Gavião (Figura 5). O local apresenta infraestruturas de apoio ao turista, como escadas e corrimões. É propício para abordagens sobre a litologia sedimentar da Formação Tianguá, uma vez que o trabalho hídrico dos riachos Boa Vista e Gavião entalha a paisagem formando vales fluviais de leito rochoso. Nas quedas d'água também é 
possível observar as camadas e a orientação da deposição sedimentar. Para complementar os lugares contém mirantes para contemplar a geomorfologia regional e espaços propíciosao banho (Figura 5).

Figura 5. Cachoeira do Gavião, um dos atrativos do Geossítio Circuito das Cachoeiras. Fotos: Autoria própria (2017).

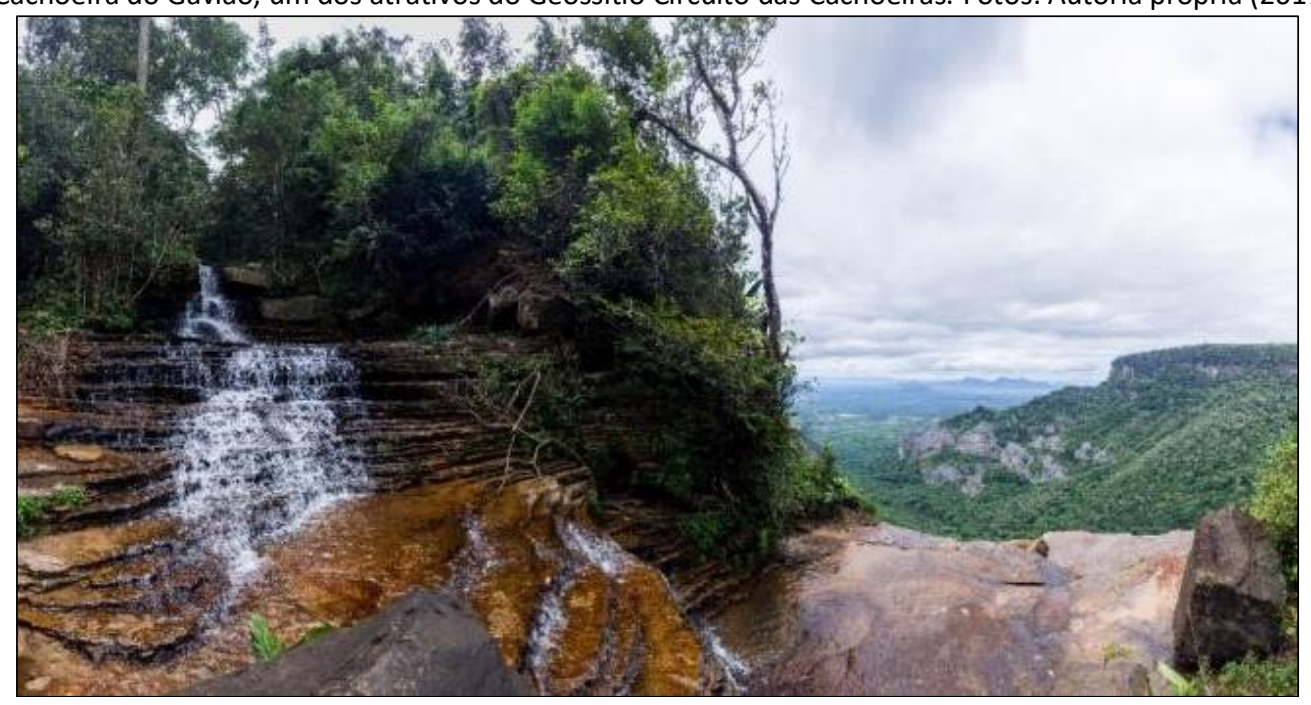

O Geossítio Gruta de Ubajara é acessível por meio de um teleférico, o qual configura um dos símbolos do Parna Ubajara, ou por uma trilha de $14 \mathrm{~km}$ entre ida e volta. A Gruta de Ubajara é a maior caverna cearense, com 1.120 metros de dutos mapeados, sendo o mais importante atrativo da UC.

A espetacularidade da Gruta de Ubajara fez com que durante décadas esse fosse o único atrativo realmente explorado turisticamente no Parna Ubajara. Porém, durante a paralização do teleférico entre os anos 2015 e 2018 a gestão teve que dinamizar o turismo, já que o acesso foi dificultado e o número de visitantes diminui. Nesse período foram abertas novas trilhas no entorno da Gruta de Ubajara e incentivado a visita a esses novos locais. Como exemplo dos novos atrativos estão uma trilha para realização de bicicleta, a construção do Mirante do Pendurado, o estabelecimento de uma estrutura para prática de arborismo próximo ao Mirante da Gameleira, realização de trilhas noturnas durante períodos de lua cheia, entre outros.

A Gruta de Ubajara possui um sistema de iluminação artificial na zona de uso intensivo, o que facilita a visitação. Ela pode ser amplamente utilizada pelo geoturismo, por ser uma feição geomorfológica que desperta a curiosidade por sua diversidade de espeleotemas (Figura 6), mas também pela relevância cultural, uma vez que o local era utilizado para prática de cultos religiosos antes de sua instituição como área protegida. 
Figura 6. Diversidade de espeleotemas do interior da Gruta de Ubajara. Fotos: Autoria própria (2017).
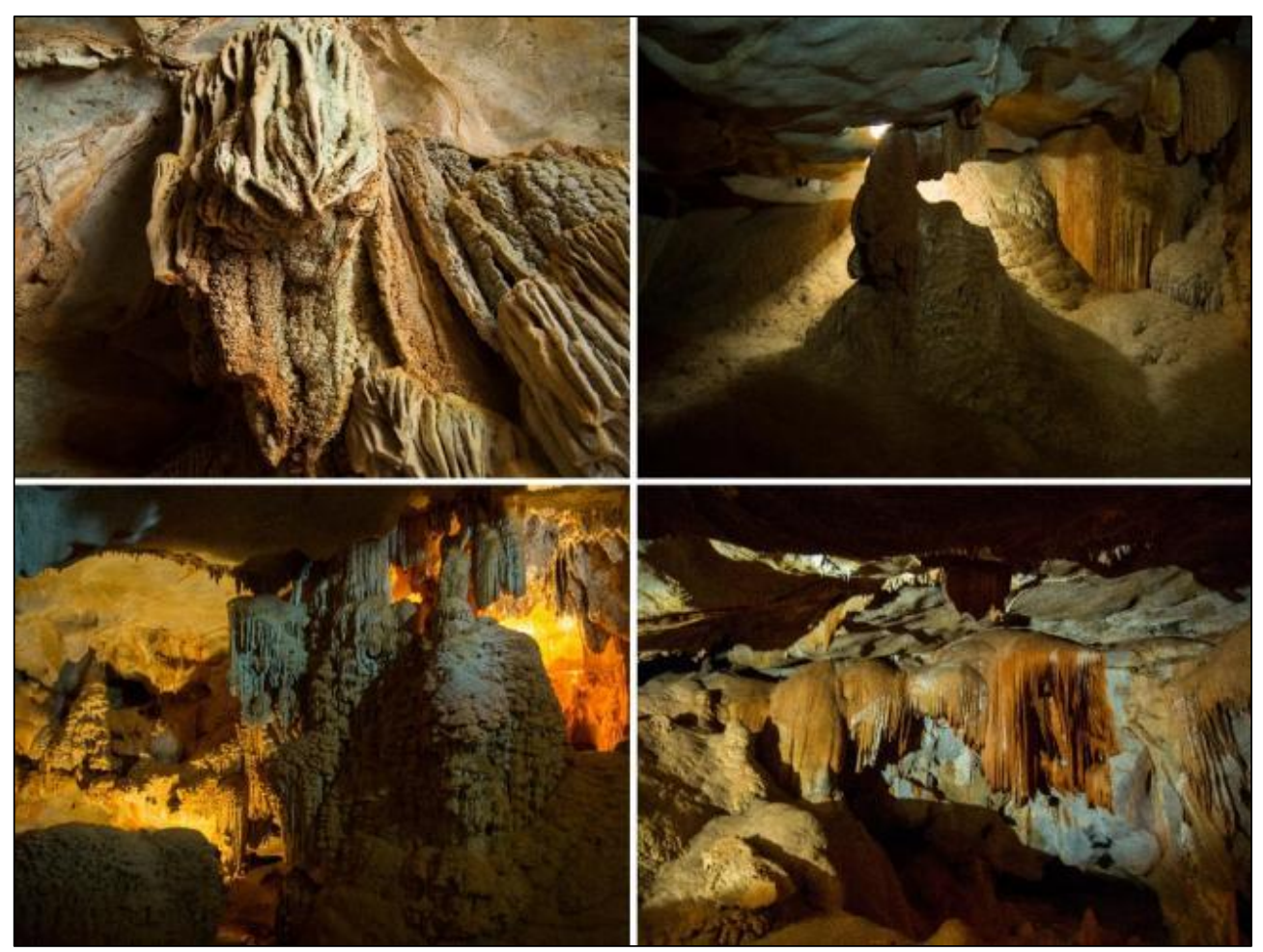

No roteiro de três dias são acrescidos os geossítios Cachoeira do Pinguruta, localizado na extremidade sul do Parna Ubajara, no município de Ubajara, e o geossítio Cachoeira do Pajé, na área de influência direta, totalizando nove locais de interesse. A ida até a Cachoeira do Pinguruta se dá por estradas vicinais e a realização de uma trilha de $3 \mathrm{~km}$ (ida e volta) de baixo grau de dificuldade, mas sem infraestrutura turística. A localização no interior de um anfiteatro erosivo fechado permite a apreciação do front do glint da Ibiapaba, marcado por escarpas areníticas de desenvolvimento vertical superior aos 50 metros, e das superfícies sertanejas (Figura 7a).

O Geossítio Cachoeira do Pajé fica no município de Ibiapina. A trilha de acesso começa às margens da CE-253, na proximidade do mirante para a cidade do Mucambo. A trilha é curta, menos de $2 \mathrm{~km}$, porém apresenta certo grau de dificuldade devido a declividade e a mata fechada. O local é utilizado para lazer, fato confirmado por relatos obtidos em conversas informais com moradores locais e pela presença de uma barragem improvisada na base da queda de 15,72 metros, que permite que a água do riacho Pajé se acumule, aprofundando o poço da cachoeira, tornando-o passível os banhos. As potencialidades para o geoturismo parte do apelo cênico do local, a exposição de rochas da Formação Jaicós e a interação da biodiversidade com a geodiversidade (Figura $7 \mathrm{~b}$ ). 
Figura 7. a) Vista panorâmica do Geossítio Cachoeira do Pinguruta. b) Interação geodiversidade e biodiversidade no Geossítio Cachoeira do Pajé. Fotos: Autoria própria (2018).

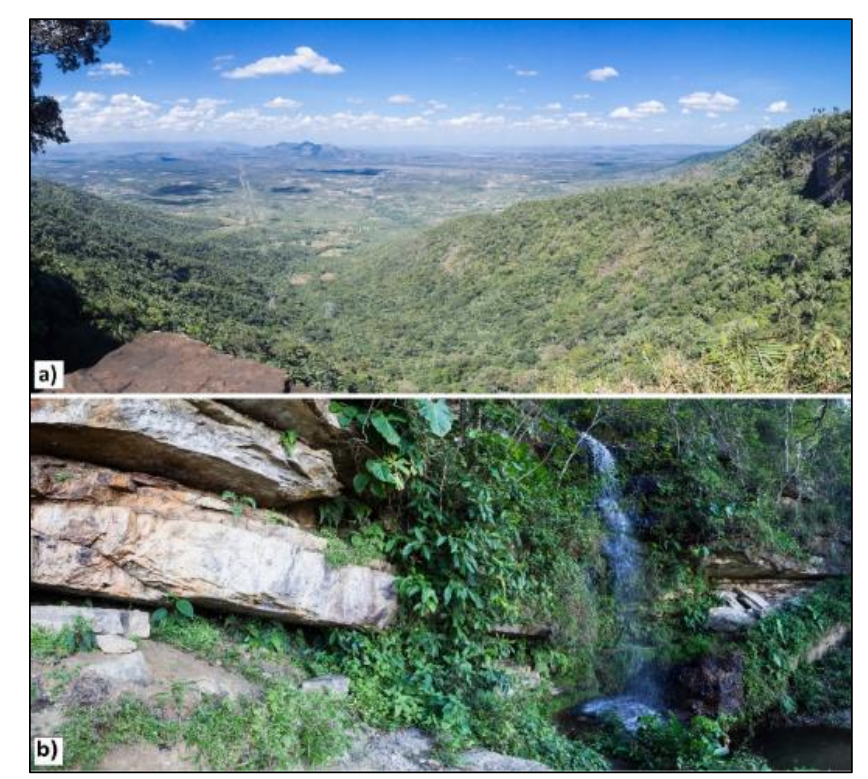

No roteiro científico são listados onze geossítios. Além dos já citados, foram acrescidos a Trilha UbajaraAraticum e as Furnas de Araticum. Não há orientação da quantidade de dias necessários para visitar todos os pontos de interesse, ficando a cargo desse turista especializado a definição da sequência e do tempo necessário. O Geossítio Trilha Ubajara-Araticum configura-se como um caminho que liga a sede municipal de Ubajara ao distrito de Araticum, no sopé do Planalto da Ibiapaba. A relevância cultural desse caminho é acrescida da importância científica, já que o local expõe a coluna estratigráfica do Parna Ubajara, exibindo na base afloramentos de rochas metamórficas das Formações Caiçaras (Figura 8a) e Frecheirinha, pertencentes ao Grupo Ubajara, e nas porções superiores arenitos da Formação Tianguá, do Grupo Serra Grande.

Figura 8. a) Afloramento de ardósias da Formação Caiçaras no leito do rio das Minas, Geossítio Trilha Ubajara-Araticum. b) Vista do Geossítio Furnas de Araticum. Fotos: Autoria própria (2017). 


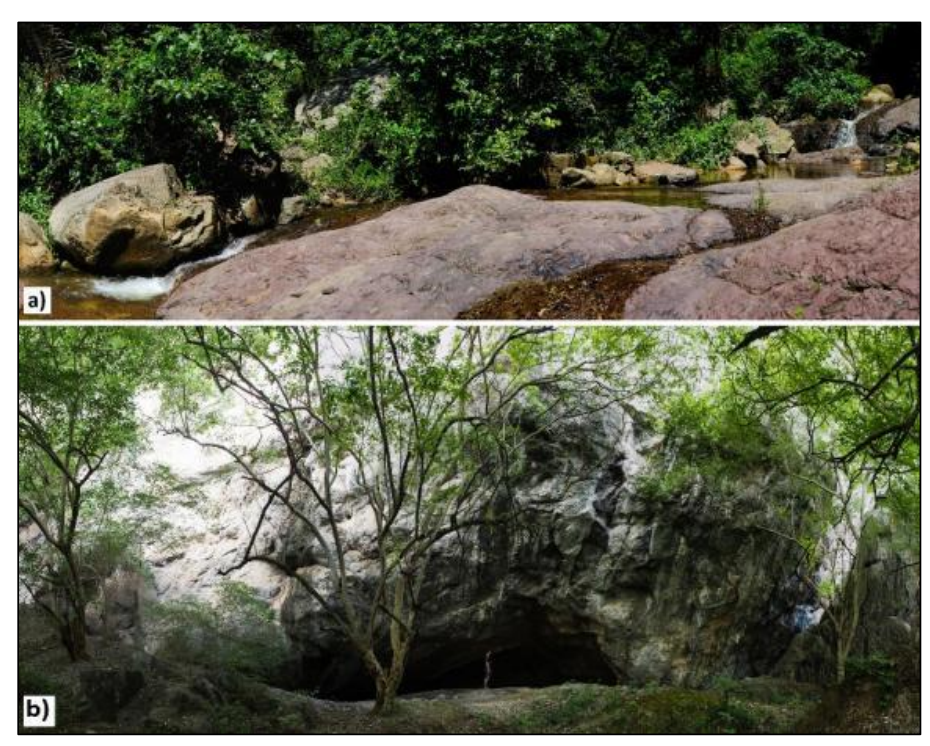

O Geossítio Furnas de Araticum está localizado na área de influência direta do Parna Ubajara, no perímetro urbano do distrito de Araticum. O local configura um inselberg cárstico (metacalcário) em meio a superfície aplainada da Depressão Sertaneja. O formato cônico típico da feição remete aos diferentes processos intempéricos sofridos. O geoturismo pode aproveitar o local mediante o seu apelo cênico (Figura 8b) e a presença de uma cavidade subterrânea com 272 metros.

Com base nos roteiros foram confeccionados três folhetos turístico-educativos. Os folhetos são diferenciados pela cor adotada, sendo o de dois dias na coloração roxa, o de três dias laranja e o científico em vermelho. É proposto que os mesmos sejam impressos em folha tamanho A4 (210 por $297 \mathrm{~mm}$ ), dobrado em três partes (totalizando seis faces). Os textos empregados foram revisados por uma profissional da área de publicidade e propaganda, com objetivo de trazer fluidez na leitura e adaptar as terminologias científicas para um vocabulário do cotidiano, mas sem perder a capacidade informativa.

O título proposto para os folhetos é "Descubra-se no Geopatrimônio do Parque Nacional de Ubajara", essa frase de impacto ocupa um terço da capa, sendo impressa na tipografia Canter com tamanho de 58 pt (Figura 9c). Na capa também estão qual o roteiro e o logo institucional do Parque Nacional de Ubajara.

Figura 9. Modelo da parte externa do folheto turístico-educativo. Fotos: Autoria própria. 


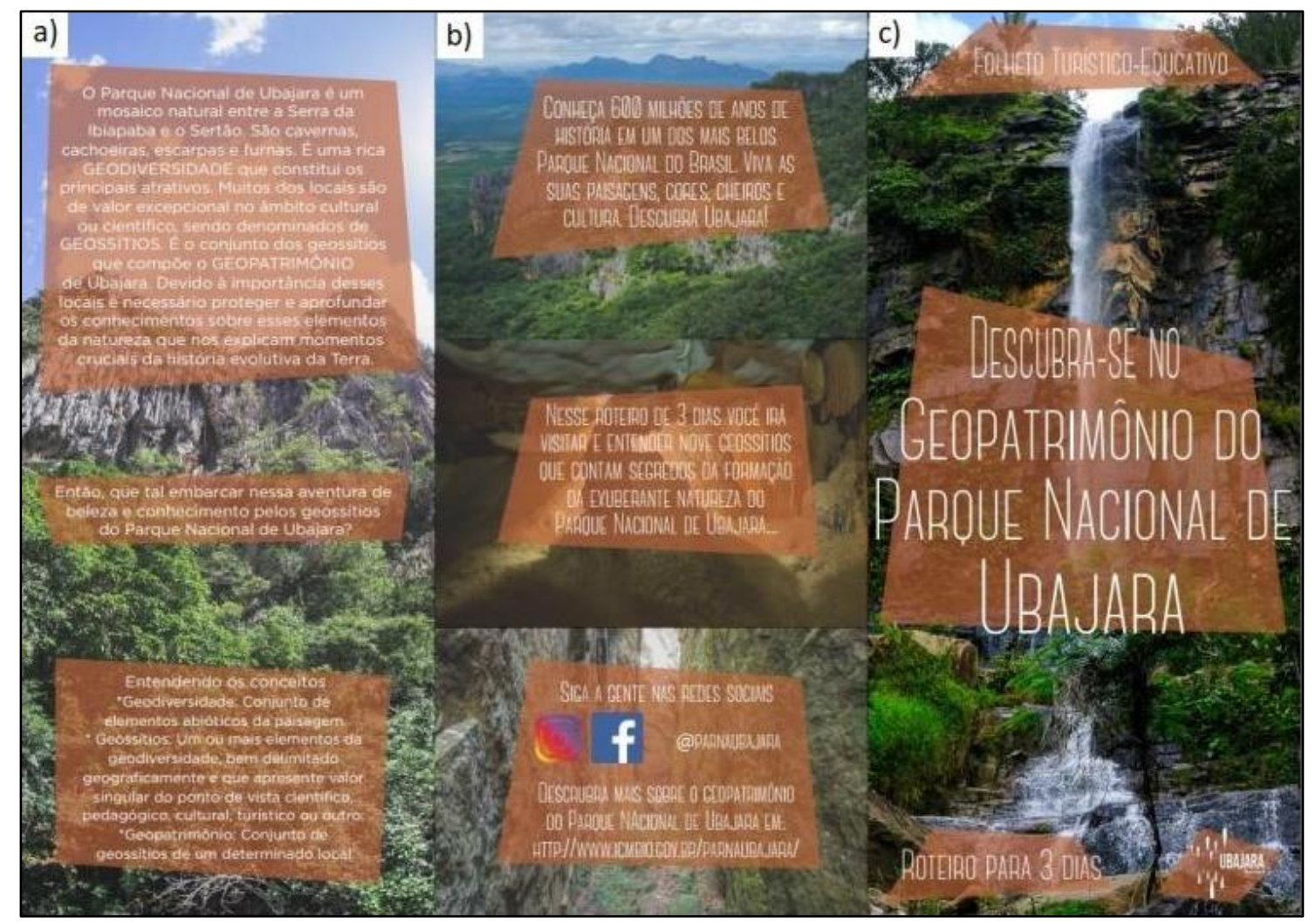

No fundo estão presentes duas outras frases de impacto que buscam despertar a curiosidade dos turistas e explicar sucintamente o que compõe o folheto (Figura 9b). São elas, "Conheça 600 milhões de anos de história em um dos mais belos Parque Nacional do Brasil. Viva as suas paisagens, cores, cheiros e cultura. Descubra Ubajara!" e "Nesse roteiro de 3 dias você irá visitar e entender sete geossítios que contam segredos da formação da exuberante natureza do Parque Nacional de Ubajara....". Salientasse que a segunda frase muda em cada folheto, já que é adaptada ao roteiro. Ainda são apresentados as redes sociais e o site do Parna Ubajara para a busca de informações sobre o seu geopatrimônio.

A outra face salienta como os elementos da geodiversidade do Parna Ubajara configuram os principais atrativos turísticos da área (Figura 9a). Também traz os conceitos de "Geodiversidade", "Geossítios" e "Geopatrimônio", termos basilares para o geoturismo, mas que não são de uso cotidiano. Dessa forma, foi necessário construir um pequeno texto interpretativo presente no Quadro 1. O texto dessa face é igual em todos os folhetos.

Quadro 1. Texto interpretativo da face interna da porção exterior. Fonte: Autoria própria.

O Parque Nacional de Ubajara é um mosaico natural entre a Serra da Ibiapaba e o Sertão. São cavernas, cachoeiras, escarpas e furnas. É uma rica GEODIVERSIDADE que constitui os principais atrativos. Muitos dos locais são de valor excepcional no âmbito cultural ou cientifico, sendo denominados de GEOSSÍTIOS. É o conjunto dos geossítios que compõe o GEOPATRIMÔNIO de Ubajara. Devido à importância desses locais é necessário proteger e aprofundar os conhecimentos sobre esses elementos da natureza que nos explicam momentos cruciais da história evolutiva da Terra. 
Então, que tal embarcar nessa aventura de beleza e conhecimento pelos geossítios do Parque Nacional de Ubajara?

Entendendo os conceitos

*Geodiversidade: Conjunto de elementos abióticos da paisagem.

*Geossítios: Um ou mais elementos da geodiversidade, bem delimitado geograficamente e que apresente valor singular do ponto de vista científico, pedagógico, cultural, turístico ou outro.

*Geopatrimônio: Conjunto de geossítios de um determinado local.

A parte interna dos folhetos também é composta por três faces, mas, diferente da externa, essas são interligadas formando um mesmo bloco de informações (Figura 10). Foram confeccionados mapas artísticos com a localização dos geossítios. Nesse contexto, cada folheto apresenta uma arte diferente, já que englobam números diferenciados de geossítios. Há um título interno "Roteiro Geoturístico do Parque Nacional de Ubajara" que se interliga com os conceitos tratados na porção externa.

A parte interna apresenta uma fotografia e um texto interpretativo sucinto para cada geossítio. Os textos trazem informações curiosas sobre os locais, como as idades das rochas, ou os nomes das feições geomorfológicas de destaque, ou os principais atores nos processos de formação. É válido apresentar os textos empregados, salientando que houve mudanças entre os folhetos devido a questão de espaço.

Figura 10. Modelo da parte interna do folheto turístico-educativo. Fonte: Autoria própria.

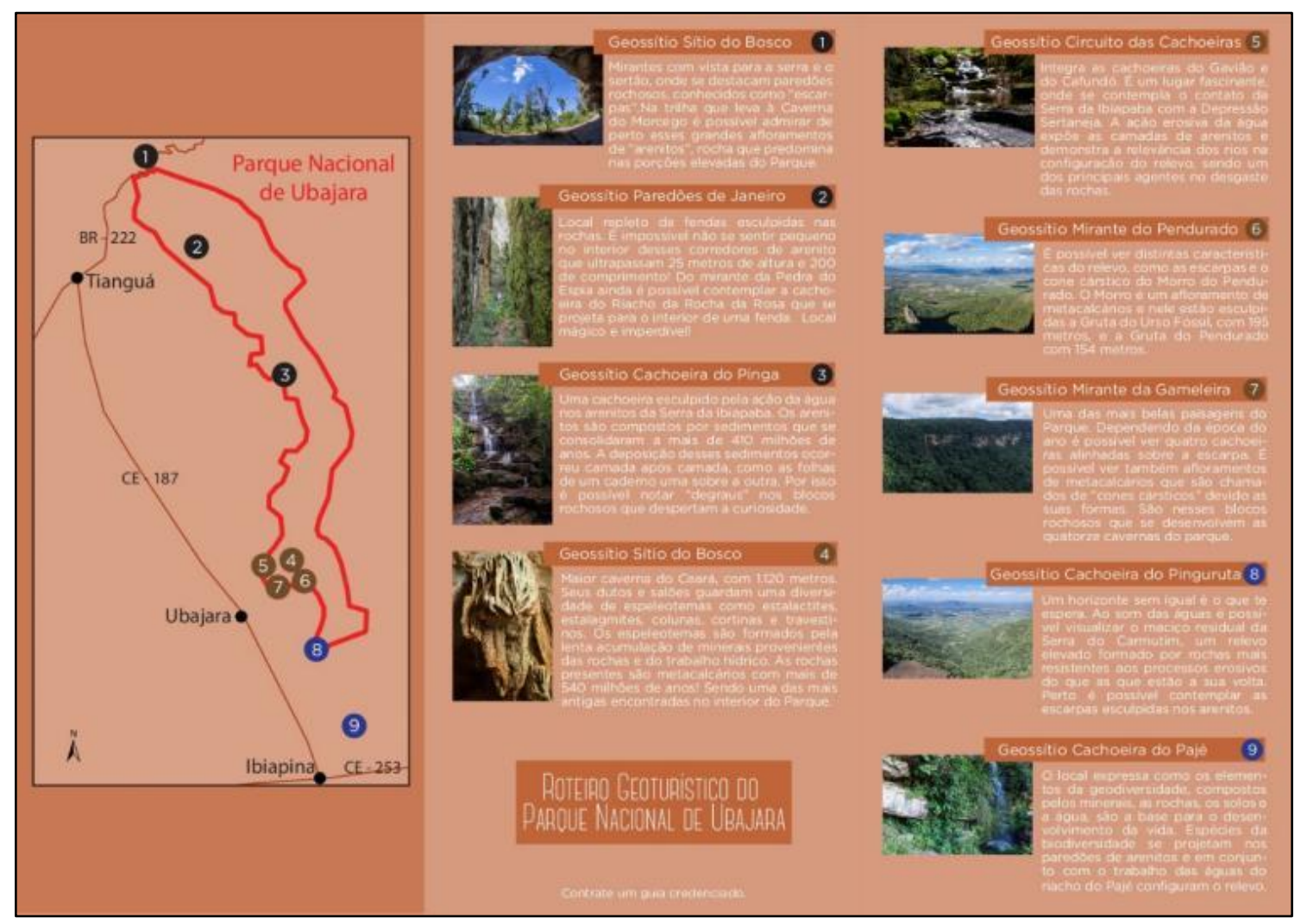


Geossítio Sítio do Bosco: Localizado no topo da Serra da Ibiapaba é composto por mirantes que permitem visualizar o contato entre a serra e o sertão. Paredões rochosos, conhecidos como escarpas, marcam a borda da Ibiapaba. Na trilha que leva à Caverna do Morcego é possível admirar e sentir de perto esses grandiosos afloramentos de arenitos, tipo de rocha sedimentar que predomina nas porções elevadas do Parque.

Geossítio Paredões de Janeiro: Mirantes, cachoeiras e fendas esculpidas em rochas. É impossível não se sentir pequeno no interior desses corredores de arenito que ultrapassam 25 metros de altura e 200 metros de comprimento. Do mirante da Pedra do Espia é possível contemplar a cachoeira do Riacho da Rocha que se projeta para o interior de uma fenda. Local mágico e imperdível!

Geossítio Cachoeira do Pinga: Uma cachoeira com dezenas de degraus esculpidos pela ação da água nos arenitos da Ibiapaba. Os arenitos são compostos por sedimentos que se consolidaram a mais de 410 milhões de anos. A deposição desses sedimentos ocorreu camada após camada, como as folhas de um caderno caem uma sobre a outra. Por isso é possível notar nos blocos rochosos esse alinhamento que desperta a curiosidade.

Geossítio Circuito das Cachoeiras: Composto pelas cachoeiras do Cafundó e do Gavião é um lugar fascinante, onde é possível contemplar o contato do Planalto da Ibiapaba com a Depressão Sertaneja e se deliciar com um banho refrescante. A ação erosiva da água expõe as camadas de arenitos e demonstra como os rios são relevantes na configuração do relevo, sendo um dos principais agentes no desgaste das rochas e transporte dos sedimentos.

Geossítio Gruta de Ubajara: Maior caverna do Ceará, com 1.120 metros de extensão. Os seus dutos e salões guardam uma infinidade de espeleotemas como estalactites, estalagmites, colunas, cortinas e travestinos. Os espeleotemas são feições formadas pela lenta acumulação de minerais provenientes das rochas e do trabalho das águas. As rochas presentes são metacalcários com mais de 540 milhões de anos! Sendo uma das mais antigas encontradas no interior do Parque Nacional de Ubajara.

Geossítio Mirante do Pendurado: Mirante onde é possível visualizar diferentes características do relevo regional, como as escarpas e o cone cárstico do Morro do Pendurado, que dá nome ao geossítio. O morro é um grande afloramento de rocha metacalcária, formada há mais de 540 milhões de anos. Lá estão esculpidas relevantes cavernas do Parque, a Gruta do Urso Fóssil, com 195 metros, e a Gruta do Pendurado com 154 metros de extensão, são alguns exemplos.

Geossítio Mirante da Gameleira: Uma das mais belas vistas do Parque, onde dependendo da época do ano é possível ver quatro cachoeiras alinhadas sobre a escarpa, os paredões de arenitos que bordeiam o Planalto da Ibiapaba e ultrapassam os 50 metros de altura. É possível ver também afloramentos de 
metacalcários que são chamados de "cones cársticos" devido as suas formas. São nesses grandes blocos rochosos que se desenvolvem as quatorze cavernas do Parque Nacional de Ubajara.

Geossítio Cachoeira do Pinguruta: Um horizonte sem igual é o que te espera. Ao som das águas é possível visualizar o maciço residual da Serra do Carmutim, um relevo elevado formado por rochas mais resistentes aos processos erosivos do que as que estão a sua volta. Perto é possível contemplar as escarpas esculpidas nos arenitos.

Geossítio Cachoeira do Pajé: O local expressa como os elementos da geodiversidade, compostos pelos minerais, as rochas, os solos e a água, são a base para o desenvolvimento da vida. Espécies da biodiversidade se projetam nos paredões de arenitos e em conjunto com o trabalho das águas do riacho do Pajé configuram o relevo.

Geossítio Trilha Ubajara-Araticum: Um passeio pelas unidades geológicas do Parque Nacional de Ubajara. Afloramentos de arenito, ardósia e metacalcário estão distribuídos nos 400 metros de desnível do topo do Planalto da Ibiapaba até à Depressão Sertaneja.

Geossítio Furnas de Araticum: Um inselberg cárstico no meio do sertão. Apresenta feições exocársticas, expressa por um campo de lapiás. Nos metacalcários é possível ver dobras que remontam eventos tectônicos sofridos desde a sua gênese a 540 milhões de anos.

Por fim, é válido pontuar que é proposital o fato dos folhetos não apresentarem descrições pormenorizadas de localização e das características das trilhas que levam aos geossítios. Enquanto uma UC de Proteção Integral, o ingresso no Parque Nacional de Ubajara só pode ser realizado com a companhia de guias credenciados. A existência dessas informações nos folhetos poderia gerar visitas sem o acompanhamento necessário, entrando em desacordo com as diretrizes da área e podendo ocasionar danos ambientais. Na parte interna do folheto é salientado "contrate um guia credenciado", entrando assim em concordância com os objetivos de conservação da UC.

\section{CONSIDERAÇÕES FINAIS}

A inserção do geoturismo no cenário mundial já configura uma realidade, vide o crescimento e difusão dos geoparques enquanto estratégia de gestão e valorização territorial. O caráter integrador e dinâmico faz com que grande parcela da população seja contemplada pelo geoturismo. A busca pelo sentir para além do ver, pelas experiências com o destino para além do "comprar" momentos, faz com que o geoturismo se configure como uma atividade que agrada aos pós-turistas e todo um novo nicho de consumidores. 
Apesar desse crescimento no contexto global, é certo afirmar que no Brasil o geoturismo ainda não alcançou o seu espaço no mercado. Mesmo que grande número de unidades de conservação tenha no geopatrimônio os seus principais atrativos turísticos, ou que paisagens geomorfológicas urbanas sejam responsáveis pelos principais recursos turísticos, ainda não há uma rede para promoção o geoturismo no território nacional.

A ausência de ferramentas institucionais de incentivo configura uma grande perda, especialmente, diante das potencialidades das diferentes regiões do país. O fato também dificulta para o geoturismo atuar enquanto ferramenta de desenvolvimento em áreas economicamente deprimidas e distantes de grandes centros, bem como promover o seu potencial para a valorização ambiental e cultural local.

Nesse contexto, é necessário que se difunda o geoturismo enquanto atividade turística viável para diferentes porções do Brasil. A instituição de roteiros, como discutido, configura uma das ferramentas de auxílio. Além de difundir os conceitos, os roteiros geoturísticos salientam a importância dos elementos do geopatrimônio para a conservação ambiental e enquanto locus para o desenvolvimento do turismo.

Os três roteiros propostos para o Parque Nacional de Ubajara demonstram a vocação da área para o geoturismo. Quase a totalidade dos atrativos turísticos do Parna Ubajara perpassam pela interação do geopatrimônio com a biodiversidade e a cultura local. A consolidação de roteiros geoturísticos ergue-se então enquanto uma possibilidade para a diversificação da oferta turística, ação buscada pelo órgão gestor e demais atores do trade turístico. O fato das propostas inserirem áreas em diferentes porções do Parna Ubajara possibilita uma melhor distribuição do fluxo de turistas, atingindo, economicamente, um maior número de pessoas e possibilitando ações diretas de conservação ambiental.

Salienta-se que esse trabalho é uma proposta inicial, focada em partes de uma etapa de roteirização turística, cabendo aos interessados o aprofundamento das análises. Porém, apesar do caráter preliminar, o presente estudo demonstra o potencial do Parque Nacional de Ubajara enquanto destino geoturístico. Outro viés dessa pesquisa é incentivar a difusão de roteiros geoturísticos estruturados, servindo como modelo para unidades de conservações brasileiras ou áreas não protegidas, urbanas ou naturais, que disponham de geopatrimônio com apelo turístico.

\section{AGRADECIMENTOS}

À Coordenação de Aperfeiçoamento de Pessoal de Nível Superior (CAPES) pela bolsa de doutorado concedida ao primeiro autor. 


\section{REFERÊNCIAS}

AROUCA. Declaração de Arouca. Disponível em: www.azoresgeopark.com/media/docs/declaracao_de_arouca_geoturismo.pdf. Acesso em: 14 de dezembro de 2018.

AZEVEDO, Úrsula Ruchkys. Patrimônio Geológico e Geoconservação no Quadrilátero Ferrífero, Minas Gerais: potencial para a criação de um Geoparque da UNESCO. 2007. 211 f. Tese (Doutorado em Geologia) - Instituto de Geociências, Universidade Federal de Minas Gerais. 2007.

BRASIL. Programa de Regionalização do Turismo, Roteiros do Brasil: módulo Operacional 7 Roteirização Turística. Brasília: Ministério do Turismo, 2007. $51 \mathrm{p}$.

BRILHA, José. Património Geológico e Geoconservação: a Conservação da Natureza na sua Vertente Geológica. Braga: Palimage Editores, 2005. 190p.

BRILHA, José. Geoheritage and Geoparks. In: REYNARD, Emmanuel; BRILHA, José (org.). Geoheritage: assessment, protection and management. Amsterdam: Elsevier, 2018. 450p. p. 323-335.

CISNE, Rebecca. Roteiro turístico, do simples ao complexo: A necessidade de reflexões. In: FÓRUM INTERNACIONAL DE TURISMO DO IGUASSU, 10., 2016, Foz do Iguaçu. Anais do X Fórum internacional de turismo do Iguassu. Foz do Iguaçu: 2016. p. 1-20.

DOWNLING, Ross. Global Geotourism: An Emerging Form of Sustainable Tourism. Czech Jornal of Tourism, v. 2, p. 59-79, 2013.

HOSE, Thomas Alfred. Selling the story of Britain's Stone. Environmental Interpretation, v. 10, n. 2, p. 16-17, 1995.

HOSE, Thomas Alfred. European geotourism: geological interpretacion and geoconservation promotion for tourists. BARETTINO, Daniel; WINBLEDON, W. A. P.; GALLEGO, Ernesto (eds). Geological heritage: its conservation and management. Madrid: Sociedad Geologica de España, p. 127-146, 200.

MEIRA, Suedio Alves. Planejamento e propostas de valorização do geopatrimônio do Parque Nacional de Ubajara, Ceará, Brasil. 2018. Tese (Doutorado em Geografia) - Departamento de Geografia, Universidade Federal do Ceará, 2020, no prelo.

MINEROPAR. Geoturismo em Curitiba. Curitiba: Mineropar, 2008. 122 p.

MOREIRA, Jasmine Cardozo. Geoturismo: Uma abordagem histórico-conceitual. Turismo e Paisagens Cársticas, v. 3, n. 1, p. 5-10, 2010

NATIONAL GEOGRAPHIC. Geoturism. Disponível: www.nationalgeographic.com/maps/geotourism/. Acesso em 14 de dezembro de 2018.

NEWSOME, David; DOWNLING, Ross. Geoheritage and Geoturism. In: REYNARD, Emmanuel; BRILHA, José (org.). Geoheritage: assessment, protection and management. Amsterdan: Elsevier, 2018. 450p. p. 305-321.

RICHTER, Monika (et al.). Elaboração de Roteiros. Rio de Janeiro: Fundação Cecierj, 2016. 327p.

SCHERER, Lisiane. Roteirização turística no espaço rural: estudo longitudinal da Rota Colonial Baumschneis - Dois Irmãos, Rio Grande do Sul, Brasil. 2014. 269p. Dissertação (Mestrado em Turismo) - Universidade de Caxias do Sul. 2014.

SILVA, Glaubécia Teixeira; NOVO, Cristiane Barroncas Maciel Costa. Roteiro turístico. Manaus: Centro de Educação Tecnológica do Amazonas, 2010. $66 \mathrm{p}$.

SPINDLER, Magda Micheline. Roteiros turísticos no espaço rural: estudo de caso do roteiro de turismo rural caminho pomerano em São Lourenço do Sul (RS), Brasil. 2013. 267p. Dissertação (Mestrado em Turismo) - Universidade de Caxias do Sul. 2013.

TILDEN, Freeman. Interpreting our heritage. 3 ed. Chapel Hill: The University of North Carolina Press, 1977.

UNESCO. UNESCO Global Geoparks. Disponível em: www.unesco.org/geoparks/.htm. Acesso em: 14 de dezembro de 2018.

ZOUROS, Nickolas. The European Geoparks Network: Geological heritage protection and local development. Episodes, v.27, n. 3, p. 165-171, 2004.

\footnotetext{
i Sítios bem delimitados geograficamente compostos por elementos da geodiversidade que apresentam valor excepcional nos critérios científico, turístico e/ou educativo (BRILHA, 2005).

ii O termo geopatrimônio é usado enquanto sinônimo de patrimônio geológico, sendo uma tradução literal do termo geoheritage, e designa o conjunto de elementos da geodiversidade com valor excepcional no que tange aos critérios cientifico, educativo ou turístico.
} 